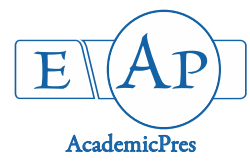

\title{
Avifaunal Assemblage along Rural-Urban Gradients in Aligarh, Uttar Pradesh, India
}

\author{
ArifSIDDIQUI, Tanveer AHMED, Afifullah KHAN* \\ Aligarh Muslim University, Department of Wildlife Sciences, Aligarh 202002, India; afifkhan@rediffmail.com( ${ }^{*}$ corresponding author); \\ tanveerwildlife@gmail.com; arifsiddiqui329@gmail.com
}

\begin{abstract}
Studies assessing the effect of urbanization on bird community structure largely carried out in developed countries and little is known about the developing region particularly in India. Bird diversity, richness, composition and guild structure was examined at urban, semi-urban, semi-rural and rural-natural sites in Aligarh, Uttar Pradesh. Each site was sampled using 90 fixed radius point counts between January and June 2016. Semi-urban site was more species rich $(2.38 \pm 0.06)$, diverse $(0.80 \pm$ $.01)$ and even $(0.90 \pm .00)$ than other three urban-rural gradient sites. Density of bird peaked at urban site $(43.09 \pm 4.7)$. Numerically, urban site was dominated by omnivore species, which was replaced by insectivorous species at semi-natural, semirural and rural-natural sites. The current information corroborates the earlier studies assessing impact of urbanization of birds and Conell's intermediate disturbance hypothesis of higher richness and diversity at intermediate disturbance.
\end{abstract}

Keywords: bird community; diversity; feeding guild; richness; urbanization

\section{Introduction}

Urbanization- the conversion of an undeveloped to metropolis landscape or built up area is sprouting rapidly worldwide. The pace of urbanization is illustrated by the fact that urbanization of the world has increased from $44.7 \%$ in 1995 to $54 \%$ in 2015 at a rate of $0.9 \%$ (UNHabitat, 2016). Sprawling urbanization coupled with resulting fragmentation decreases basic requirements of animals and isolate native species genetically and demographically (Ricketts, 2001). This extirpates native species (Blair, 1996; Chace and Walsh, 2006), alter the behavior of species in human modified areas (Magle and Angelon, 2011) and cause biotic homonization (McKinney, 2006).

Urbanization adversely impacts avifauna by decreasing natural food availability, nesting sites, influencing body condition, breeding success, nestling survival and increasing competition, stress, increasing bioaccumulation of pollutants and rate of mortality due to collision (Seress and Liker, 2015). A combination of these factors in urbanized area significantly influences species abundance, richness, diversity, biomass and composition (Blair, 1996; Blogger et al., 1997; Jokimaki et al., 2002; Chace and Walsh, 2006). Increasing urbanization typically increase biomass and density/abundance of bird (Chace and Walsh, 2006). Species richness and diversity either decline monotonously with increasing urbanization (Miller et al., 2003; Bhatt and Joshi, 2011; Sengupta et al., 2013; Sanz and Caula, 2014; Koparde and Raote, 2016; Leveau et al., 2017) or peaks at intermediate level of urbanization and then decreasing at higher levels (Jokimaki and Suhonen, 1996; Blair, 1996; Marzluff, 2001; Chace and Walsh, 2006; Graham and Duda, 2011). The latter trend is more ubiquitous though a recent study supported both the patterns (Lepczyk et al., 2008). Increasing urbanization causes synurbization of bird assemblage observed in many parts of the world (Beissinger and Osborne, 1983; Sengupta et al., 2013; Pal et al., 2019). An urbanized area attracts "urban exploiter/adapters", more natural supports "urban avoiders/intolerant" and a ecotone between the two to "suburban adaptable" (Blair, 1996). However, most of our knowledge on effect of urbanization stems from studies in developed countries and little is known about the developing region despite the burgeoning urbanization.

India supports around 1300 species of avifauna accounting $13 \%$ of the world (Grimmet et al., 1998). Though India has experienced a rapid urbanization; $26.6 \%$ to $37 \%$, between 1995 and 2015 (UN-Habitat, 2016), yet only scarce evidences existed on the effect of urbanization, restricted to some biogeographic zones such as Himalaya (Bhatt and Joshi, 2011; Naithani and Bhatt, 2012), coast (Sengupta et al., 2013; Kale et al., 2018) and Deccan plateau (Pal et al., 2019) and none in Gangetic plains. To fill the 
422

knowledge gap about effect of urbanization, present study is an attempt to investigate pattern of richness, diversity, and evenness, density along with functional diversity, dominant feeding guilds and species restricted at various urban-rural gradient sites in Aligarh, Uttar Pradesh.

\section{Materials and Methods}

\section{Study area}

Aligarh district $\left(27^{\circ} 29^{\prime} \mathrm{N}\right.$ to $28^{\circ} 1^{\prime} \mathrm{N}$ latitude and $77^{\circ}$ $29^{\prime}$ E to $79^{\circ} 40^{\prime}$ E longitude) in north Indian state of Uttar Pradesh, India, encompasses an area of 3650 sq. $\mathrm{km}$ between two perennial rivers of Himalayan origin viz. the Ganga and Yamuna. Aligarh is characterized by monsoonal type of climate with three distinct seasons; winter (November to February), summer (late March to June), monsoons or rainy season, (July to October). During winters temperature drops down to $10{ }^{\circ} \mathrm{C}$ during night which rises up to a maximum of $44^{\circ} \mathrm{C}$ during summers. The district is densely populated $(1,007$ person/sq. $\mathrm{km})$ with a total population of 36,73,889 persons (Census of India, 2011). Four sampling sites representing typical form of urban (163.5 ha), semiurban (208.22 ha), semi-rural (165.13 ha) and rural-natural ( $159.13 \mathrm{ha}$ ) were selected based on increasing built up area and decreasing natural vegetation cover (Table 1, Figs. 1-2).

\section{Methodology}

Sampling of birds at each rural-urban gradient site was conducted through $30 \mathrm{~m}$ closed width point count method between January and June 2016. Each point count lasted for 15 min during which bird species were recorded along with their numbers. A total 90 point count stations were established randomly maintaining a minimum interval of 250-300 $\mathrm{m}$ at each site. Sampling locations were decided according to the visibility and accessibility. Birds were sampled three times at each point station periodically. Bird species were classified into various dietary guilds viz. carnivore, frugivore, omnivore, insectivore, granivore, piscivore and nectivore following Ali and Ripley (1987).

The species encountered during all sampling point were added cumulatively to determine the total number of species for each sampling sites. Density of bird was calculated by dividing total bird encounter at a point by the area covered. Bird richness (Margalefs), diversity (Shannon's diversity) and evenness were calculated using PAST 3.0. The abundance each of bird species was assessed on an arbitrary frequency scale as per the following categories: rare $=1-5$ sightings, common $=6-25$ sightings, abundant $=26-50$ sighting, very abundant $=>50$ sightings. The difference in mean density, diversity, richness and evenness across the various urban gradient sites was verified through One-way Analysis of variance (ANOVA) in SPSS ver. 20.0. Frequency of sighting among various sampling sites was compared using Chi-square test.

\section{Results}

A total 63 species were observed at various rural-urban gradient sites representing 14 orders and 39 families. Richness of avifauna was maximum $(2.38 \pm .06)$ at semiurban site and minimum $(1.08 \pm .05)$ at urban site (Table $2)$. Bird richness varied significantly across the study sites $\left(\mathrm{F}_{3,397}=84.89, \mathrm{P}<0.01\right)$. Semi-urban site was found to be more diverse $(0.80 \pm .01)$ than rural-natural and semi-rural sites $(0.74 \pm .01$ each). Diversity of birds also varied significantly among all four sites $\left(\mathrm{F}_{3,397}=86.65, \mathrm{P}<0.01\right)$. The distribution of bird species were more even at semiurban site $(0.90 \pm .00)$ compared with other three sites (Table 2). Urban site supported highest density of birds (43.09 \pm 4.7 birds/hectare) while rural-natural site to minimum, with a value of $30.77 \pm 2.4$ individuals of birds per hectare (Table 2). However, density of birds across various rural-urban gradient sites was not statistically significant.

Of the 63 species encountered, 21 species (33.3\%) and 12 species $(19.0 \%)$ showed a exclusive distribution reported from four and one sampling site respectively (Table 3). Among the exclusively occurring species, eight (66.6\%) were found at rural-natural site and four species (33.3\%) occurred at semi-rural site only (Table 3 ). Two species were very abundant at urban site: rock pigeon (Columba livia) and laughing dove (Spilopelia senegalensis). Semi-urban site was numerically dominated by rose-ringed parakeet (Psittacula krameri), common myna (Acridotheres tristis),

Table 1. Description of various urban-rural gradient sites in Aligarh, Uttar Pradesh, India

\begin{tabular}{|c|c|c|}
\hline Sampling sites & Locality & Description \\
\hline $\begin{array}{c}\text { Urban } \\
\text { (163.58 ha) }\end{array}$ & $\begin{array}{l}\text { Aligarh city enclosing Rasalgunj, Railway } \\
\text { road, Upper court, Gandhi Nagar } \\
\left(27^{\circ} 53^{\prime} 14.42^{\prime \prime} \mathrm{N} \& 78^{\circ} 4^{\prime} 0.73^{\prime \prime} \mathrm{E}\right)\end{array}$ & $\begin{array}{l}\text { These areas were a part of the old city converted into human habitation more than a century ago } \\
\text { and are devoid of natural vegetation except a few trees such as Ficus religiosa, Ficus infectora, } \\
\text { Azaradiracta indica, Delonex regia, Zizypus mauritiana. This site was dominated by built up } \\
\text { (138.13 ha), few area under lawns (7.92ha) and natural vegetation (17.52 ha). }\end{array}$ \\
\hline $\begin{array}{l}\text { Semi- Urban } \\
(208.22 \text { ha })\end{array}$ & $\begin{array}{l}\text { Aligarh Muslim University campus and } \\
\qquad \text { Naqvi Park } \\
\left(27^{\circ} 54^{\prime} 48.14^{\prime \prime} \mathrm{N} \& 78^{\circ} 4^{\prime} 32.81^{\prime \prime} \mathrm{E}\right)\end{array}$ & $\begin{array}{c}\text { These area were characterized by built up area ( } 84.30 \mathrm{ha}) \text { along with patches of lawns (29.23ha) } \\
\text { and tree cover (94.69ha) representing indigenous floral elements such as Bougainvillea glabra, } \\
\text { Polyathia longifolia, Holoptelea integrifolia, Azadirachta indica, Baubinia purpurea, Firmiana } \\
\text { simplex Melia azedarack, Grevillea rubusta, Terminalia arjuna, Delonix regia, Ficus drupaceae, } \\
\text { Ficus rumphi, Sterculia alata, Dalbergia sissoo. }\end{array}$ \\
\hline $\begin{array}{l}\text { Semi-rural } \\
(165.13 \mathrm{ha})\end{array}$ & $\begin{array}{c}\text { Sagar complex } \\
\left(27^{\circ} 56^{\prime} 46.15^{\prime \prime} \mathrm{N} \& 78^{\circ} 4^{\prime} 56.34^{\prime \prime} \mathrm{E}\right)\end{array}$ & $\begin{array}{l}\text { Recently developing area where high construction was in progress. This site possesses some } \\
\text { natural floral elements (17.52ha) along with cultivated area }(9.17 \mathrm{ha}) \text { as the area has recently } \\
\text { come under human habitation }(79.34 \mathrm{ha}) \text {. }\end{array}$ \\
\hline $\begin{array}{l}\text { Rural-Natural } \\
(159.13 \mathrm{ha})\end{array}$ & $\begin{array}{l}\text { Chherrat villages and Heinz Pvt. Ltd. } \\
\left(27^{\circ} 57^{\prime} 19.39^{\prime \prime} \mathrm{N} \& 78^{\circ} 5^{\prime} 41.19^{\prime \prime} \mathrm{E}\right)\end{array}$ & $\begin{array}{l}\text { This site was characterized by largely croplands ( } 62.65 \mathrm{ha} \text { ), a large patch of natural vegetation } \\
\text { dominated by Prosopis juliflora ( } 66.61 \mathrm{ha} \text { ) and village ( } 19.98 \mathrm{ha}) \text {. }\end{array}$ \\
\hline
\end{tabular}




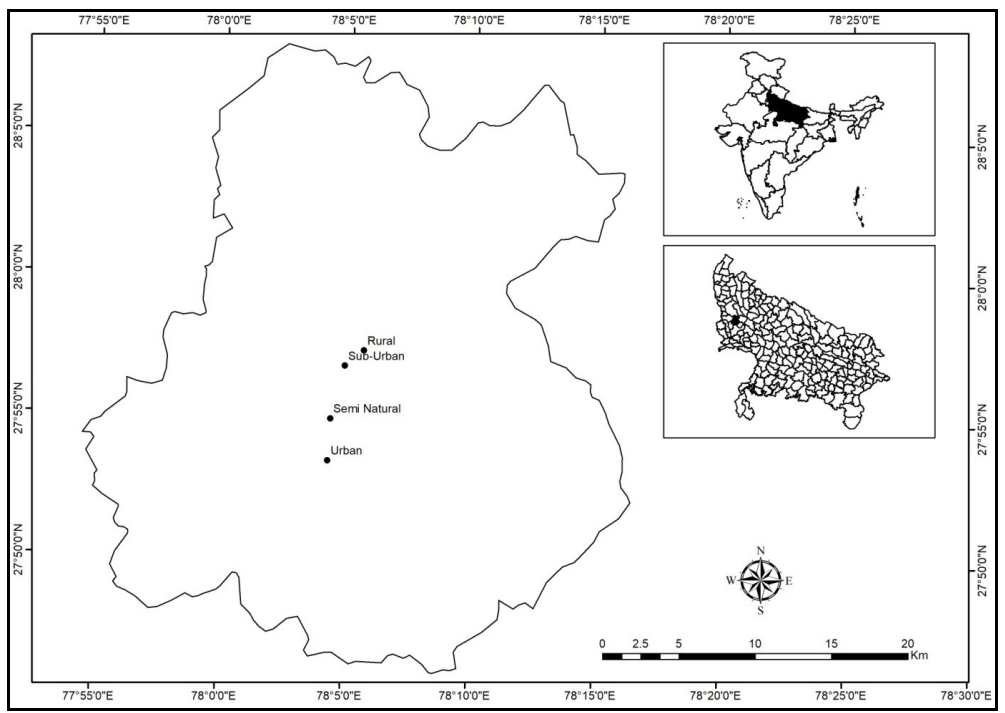

Fig. 1. Bird sampling sites in Aligarh district, Uttar Pradesh, India

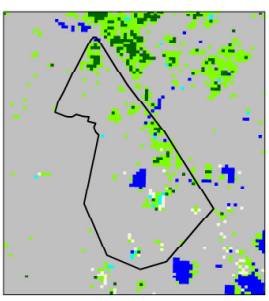

a. Urban

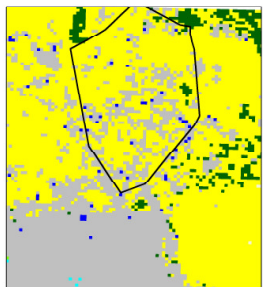

c. Semi-rural

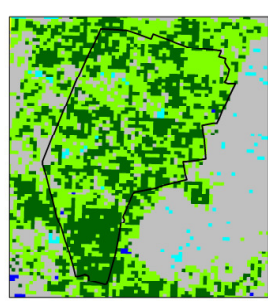

b. Semi-natural

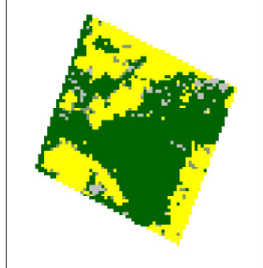

d. Rural-natural

Green spaces (Lawn and Parks)

$\square$ Agriculture

Tree Plantation

Built up

Water Body

Impervious spaces

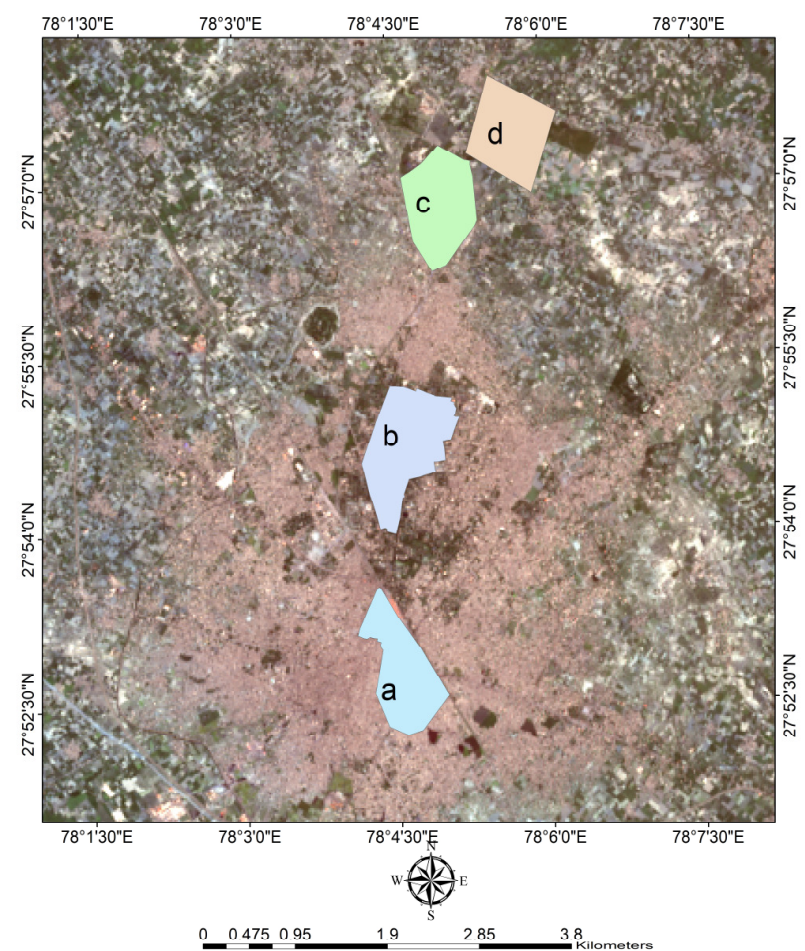

Fig. 2. Study sites in Aligarh, Uttar Pradesh, India a) Urban, b) Semi-urban c) Semi-rural d) Rural-natural

house crow (Corvus splendens), Eurasian collard dove (Streptopelia decaocto), jungle babbler (Turdoides striata) and black kite (Milvus migrans). Laughing dove, rock pigeon, house crow and Asian pied starling (Gracupica contra) was found very abundant at rural-natural site again. The sighting frequency of most of the species of birds was significantly different across the urban gradient sites except few rarely sighted species (Table 3 ).

Bird species from seven guilds were observed with six feeding guilds present at three sites i.e. urban, semi-natural and semi-rural. Species of nectivorous guild were recorded from rural site only. Urban site was found to be numerically dominated by omnivore species which was replaced by insectivore species at other three urban-rural gradient sites. Semi-urban and semi-rural site had almost similar guild composition. At both the site, dominant guild was insectivore which was followed by omnivore (Fig. 3). However, the dominant guild; insectivores, was followed by piscivorous guild at rural site. Very few omnivore species occurred at rural site (Fig. 3). 

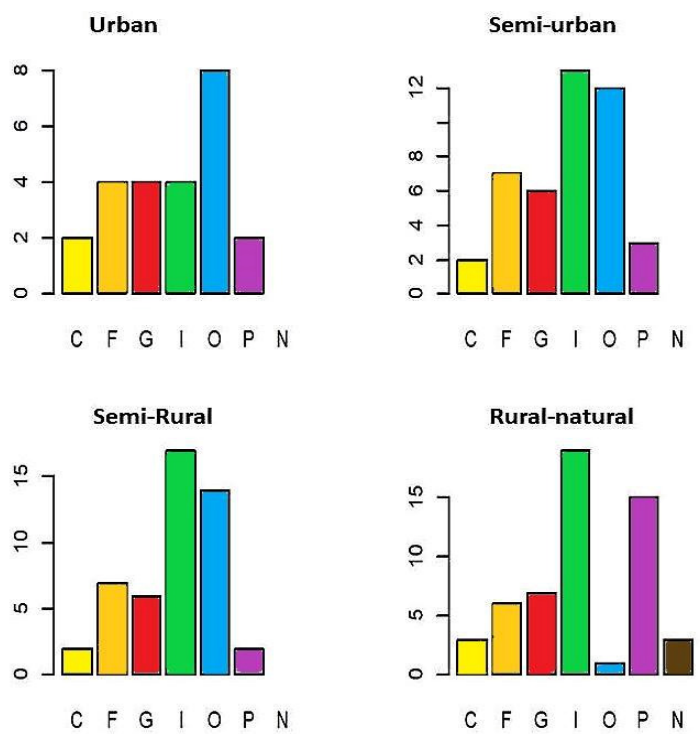

Fig. 3. Feeding guild of birds along rural-urban gradients sites in Aligarh, Uttar Pradesh ( $\mathrm{C}=\mathrm{Carnivore}, \mathrm{F}=\mathrm{Frugivore}$, $\mathrm{G}=$ Granivore, $\mathrm{I}=$ Insectivore, $\mathrm{N}=$ Nectivore, $\mathrm{O}=$ Omnivore, $\mathrm{P}=$ Piscivore)

Table 2. Bird community structure at various sampling sites in Aligarh, Uttar Pradesh, India

\begin{tabular}{ccccccc}
\hline Sampling sites & Families & Species & $\begin{array}{c}\text { Density } \\
\text { (Birds/hectare) }\end{array}$ & Richness & Diversity \\
\hline Urban & 17 & 24 & $43.09 \pm 4.7$ & $1.08 \pm .05$ & $0.43 \pm .02$ \\
Semi- Urban & 28 & 43 & $36.16 \pm 3.3$ & $2.38 \pm .06$ & $0.80 \pm .01$ & $0.72 \pm .02$ \\
Semi-rural & 35 & 48 & $37.27 \pm 4.5$ & $2.18 \pm .06$ & $0.74 \pm .01$ \\
Rural-natural & 34 & 55 & $30.77 \pm 2.4$ & $2.22 \pm .06$ & $0.74 \pm .01$ \\
Overall & 39 & 63 & $36.82 \pm 1.9$ & $1.99 \pm .04$ & $0.69 \pm .01$ \\
\hline
\end{tabular}

Table 3. Frequency of sighting of bird species at various urban gradient sites in Aligarh, Uttar Pradesh, India

\begin{tabular}{|c|c|c|c|c|c|}
\hline Species & Urban & Semi urban & Semi-rural & Rural-natural & $\begin{array}{c}\text { Chi-Square } \\
\text { (P value) }\end{array}$ \\
\hline Ashy Prinia (Prinia socialis) & 3 & 6 & 13 & 18 & $<0.01$ \\
\hline Asian Koel (Eudynamys scolopaceus) & 2 & 30 & 7 & 15 & $<0.01$ \\
\hline Asian Paradise Flycatcher (Terpsiphone paradise) & 0 & 0 & 0 & 1 & NA \\
\hline Asian pied Starling (Gracupica contra) & 0 & 22 & 55 & 23 & $<0.01$ \\
\hline Bank Myna (Acridotheres ginginianus) & 6 & 0 & 30 & 14 & $<0.01$ \\
\hline Bay-backed Shrike (Lanius vittatus) & 0 & 2 & 1 & 0 & NA \\
\hline Black Drongo (Dicrurus macrocercus) & 0 & 30 & 36 & 17 & $<0.01$ \\
\hline Black Kite (Milvus migrans) & 21 & 50 & 18 & 16 & $<0.01$ \\
\hline Black -winged Stilt (Himantopus bimantopus) & 0 & 0 & 2 & 1 & NA \\
\hline Brahminy Starling (Sturnia pagodarum) & 0 & 1 & 2 & 1 & NA \\
\hline Brown-headed Barbet (Megalaima zeylanica) & 2 & 19 & 5 & 8 & $<0.01$ \\
\hline Brown rock Chat (Cercomela fusca) & 37 & 3 & 44 & 8 & $<0.01$ \\
\hline Cattle Egret (Bubulcus ibis) & 1 & 6 & 6 & 12 & $<0.05$ \\
\hline Chestnut -shoulderd Petronia (Petronia superciliaris) & 0 & 0 & 1 & 0 & NA \\
\hline Common Hoopoe (Upupa epops) & 0 & 0 & 5 & 4 & NA \\
\hline Common Moorhen (Gallinula chloropus) & 0 & 2 & 0 & 3 & NA \\
\hline Common Myna (Acridotheres tristis) & 24 & 73 & 25 & 46 & $<0.01$ \\
\hline Common Sandpiper (Actitis hypoleucos) & 0 & 0 & 2 & 1 & 0 \\
\hline Common Tailorbird (Orthotomus sutorius) & 0 & 0 & 0 & 6 & $<0.01$ \\
\hline Coppersmith Barbet (Megalaima haemacephala) & 0 & 5 & 5 & 1 & NA \\
\hline Egyptian Vulture (Neophron percnopterus) & 0 & 0 & 0 & 1 & NA \\
\hline Eurasian collard Dove (Streptopelia decaocto) & 15 & 54 & 42 & 44 & $<0.01$ \\
\hline Indian Thick-knee (Burbinus indicus) & 0 & 0 & 0 & 1 & NA \\
\hline Greater Coucal (Centropus sinensis) & 0 & 6 & 6 & 10 & $<0.05$ \\
\hline
\end{tabular}




\begin{tabular}{|c|c|c|c|c|c|}
\hline Green Bee-eater (Merops orientalis) & 0 & 0 & 16 & 23 & $<0.01$ \\
\hline Grey Francolin (Francolinuspondicerianus) & 0 & 0 & 0 & 10 & $<0.01$ \\
\hline Grey Hornbill (Ocyceros birostris) & 3 & 24 & 4 & 12 & $<0.01$ \\
\hline House Crow (Corvus splendens) & 13 & 65 & 58 & 44 & $<0.01$ \\
\hline House Sparrow (Passer domesticus) & 18 & 3 & 16 & 4 & $<0.01$ \\
\hline House Swift (Apus nipalensis) & 10 & 1 & 2 & 0 & $<0.01$ \\
\hline Indian bush Lark (Mirafra erythroptera) & 0 & 0 & 5 & 0 & $<0.01$ \\
\hline Indian golden Oriole (Oriolus oriolus) & 0 & 1 & 2 & 0 & NA \\
\hline Indian Jungle Crow (Corvus macrorhynchos) & 1 & 7 & 1 & 9 & $<0.01$ \\
\hline Indian Peafowl (Pavo cristatus) & 0 & 11 & 3 & 35 & $<0.01$ \\
\hline Indian Robin (Saxicoloides fulicatus) & 0 & 7 & 19 & 7 & $<0.01$ \\
\hline Indian Roller (Coracias benghalensis) & 0 & 1 & 3 & 0 & NA \\
\hline Indian Silverbill (Lonchura malabarica) & 0 & 2 & 16 & 9 & $<0.01$ \\
\hline Jungle Babbler (Turdoidesstriata) & 1 & 51 & 8 & 44 & $<0.01$ \\
\hline Large grey Babbler (Turdoides malcolmi) & 0 & 0 & 12 & 31 & $<0.01$ \\
\hline Laughing Dove (Spilopelia senegalensis) & 55 & 44 & 68 & 39 & 0.05 \\
\hline Oriental Magpie-robin (Copsychus saularis) & 0 & 14 & 2 & 1 & $<0.01$ \\
\hline Paddy field Pipit (Anthus rufulus) & 0 & 0 & 4 & 0 & $<0.01$ \\
\hline Plain Martin (Riparia paludicola) & 0 & 0 & 1 & 0 & NA \\
\hline Plain Prinia (Prinia inornata) & 0 & 0 & 4 & 3 & NA \\
\hline Indian pond Heron (Ardeola grayii) & 0 & 2 & 0 & 7 & $<0.01$ \\
\hline Purple Sunbird (Nectarinia asiatica) & 2 & 15 & 8 & 7 & 0.05 \\
\hline Red-headed Bunting (Emberiza bruniceps) & 0 & 0 & 0 & 1 & NA \\
\hline Red-naped Ibis (Pseudibispapillosa) & 0 & 0 & 0 & 1 & NA \\
\hline Red-vented Bulbul (Pycnonotus cafer) & 14 & 47 & 43 & 28 & $<0.01$ \\
\hline Red-wattled Lapwing (Venellus indicus) & 0 & 7 & 20 & 20 & $<0.01$ \\
\hline Rock Pigeon (Columba livia) & 81 & 45 & 62 & 50 & $<0.01$ \\
\hline Rofous Tree Pie (Dendrocitta vagabunda) & 0 & 12 & 2 & 5 & $<0.01$ \\
\hline Rose-ringed Parakeet (Psittacula Krameri) & 27 & 74 & 17 & 36 & $<0.01$ \\
\hline Scaly-breasted Munia (Lonchura punctulata) & 0 & 0 & 0 & 1 & NA \\
\hline Shikra (Accipiter badius) & 2 & 2 & 1 & 4 & NA \\
\hline Spotted Dove (Spilopelia chinensis) & 0 & 1 & 0 & 2 & NA \\
\hline Spotted Owlet (Athene brama) & 0 & 1 & 0 & 1 & NA \\
\hline White-breasted Waterhen (Amaurornis phoenicurus) & 0 & 3 & 0 & 7 & $<0.01$ \\
\hline White-naped Woodpecker (Chrysocolaptes festivus) & 0 & 1 & 0 & 2 & NA \\
\hline White-throated Kingfisher (Halcyon smyrnensis) & 2 & 4 & 13 & 13 & $<0.01$ \\
\hline White Wagtail (Motacilla alba) & 0 & 2 & 1 & 2 & NA \\
\hline Wire-tailed Swallow (Hirundo smithii) & 1 & 0 & 0 & 1 & NA \\
\hline Yellow-footed Green Pigeon (Treron phoenicoptera) & 1 & 37 & 7 & 9 & $<0.01$ \\
\hline
\end{tabular}

\section{Discussion}

The current study concludes that avifaunal richness, diversity and composition are influenced by urbanization in Aligarh district as well consistent with the previous studies in India (Naithani and Bhatt, 2012; Sengupta et al., 2014; Kale et al., 2018; Pal et al., 2019). The low richness and diversity of birds in urban area as compared to the semiurban, semi-rural and rural-natural is in line with earlier studies across the globe (Blair, 1996; Marzluff, 2001; McKinney, 2002; Pauchard et al., 2006; McKinney, 2008; Garaffa et al., 2009; Naithani and Bhatt, 2012; Sengupta et al., 2013; Pal et al., 2019). Moreover, the high bird species diversity and richness at semi-urban site supported Conell's intermediate disturbance hypothesis (Conell, 1978) in line with Pal et al. (2019) in India and outside (Jokimaki and
Suhonen, 1993; Marzluff, 2005). This however, contradicts Kale et al. (2018); results of that study supported Gray's increasing disturbance hypothesis in Amravati, central India. The higher diversity of birds in semi-urban site could be related to higher habitat heterogeneity at semi-natural site. Our semi-urban site, having well-established ground, shrub cover, canopy cover along with concrete structure; would be expected to provide the more foraging, nesting and shelter opportunities for a range of species that urban site. Many studies have highlighted heterogeneous landscape provides more niches to exploit and hence supports high diversity (Bohning-Gaese, 1997; Fahrig et al., 2011; Bonilla et al., 2012; Katayama et al., 2014). Consistent with earlier studies in India (Kale et al., 2018; Pal et al., 2019) and outside as well (Chace and Walsh, 2006 and references therein), the high density of birds in urban 
426

area supported resource concentration hypothesis (Pickett et al., 2001).

Bird species composition was found different among the various urban-rural gradient sites. Some bird species viz. Asian paradise flycatcher (Terpsiphone paradise), Indian thick-knee (Burbinus indicus), red-headed Bunting (Emberiza bruniceps), red-naped ibis (Pseudibis papillosa), scaly-breasted munia (Lonchura punctulata), common tailorbird (Orthotomus sutorius) and Egyptian vulture (Neophron percnopterus) were restricted to rural site only. Restricted distribution of these species could be related to their habitat association. Asian paradise flycatcher is summer visitor to northern India and inhabits wooded areas and secondary forest. Eurasian thick-knee is a bird of dry scrub, stony dry riverbeds with scrub. Red-naped ibis prefer freshwater marshes and large lakes, flooded grassland and paddy-field. Tall wet grassland, reedy marshes, sugarcane field and scrub near cultivation are home of scaly-breasted munia (Grimmet et al., 2015). Increasing vegetation cover increases the probability of having a breeding site of Egyptian vulture while decreases with increasing urbanized surface area (Sara and Vittorio, 2003). Urban, semi-urban and semi-rural sites in Aligarh district lack these habitat, hence cause of their restricted distribution. Chestnutshoulder petronia (Petronia superciliaris), Indian bush lark (Mirafra erythroptera), paddy field pipit (Anthus rufulus) and plain martin occurred at semi-rural site only. Chestnutshoulder petronia (Gymnoris xanthocollis) inhabits thorn scrub trees at edges of cultivation. Indian bushlark is a bird of stony scrub and fallow cultivation. Paddy field pipit (Anthus rufulus) resides in short grassland and Plain martin around rivers and lakes (Grimmet et al., 2015). Semi-rural supports these habitats; hence correspond to their restricted distribution.

The high abundance of rock pigeon and laughing dove in urban landscape is in accordance with the previous studies highlighting higher abundance of synanthropic/urban adaptors species in urban landscape (Blair, 1996; Jokimaki et al., 2002; Bhatt and Joshi, 2011). Granivore species are benefitted by public housing as these estates contain anthropogenic food which could support their higher abundance (Lim and Sodhi, 2004). It is important to note that a synanthropic species i.e. house sparrow (Passer domesticus) was not abundant at urban site implying decline of this species as many urban habitats around the world (Summers-Smith, 2007; Joshi and Bhatt, 2011; Mondak, 2017).

There is a clear distinction between urban and ruralnatural sites in terms of various feeding guild. Urban site was dominated by omnivore guild whereas insectivore guild dominated the semi-urban, semi-rural and rural-natural site. Dominancy of omnivore species at urban site has also been observed by Beissinger and Osborne (1982), Sengupta et al. (2014) and Pal et al. (2019). It could be related with higher house density in comparison with other urban-rural gradients sites as reported by Sengupta et al. (2014). Number of insect eating birds increases from urban to ruralnatural site. Other studies have also found that insectivores were more abundant in rural habitats (Kark et al., 2007; Conole and Kirkpatrick, 2011) and the proportion decreased with increasing percentage of built up area (Lim and Sodhi, 2004). Furthermore, insectivores are sensitive to environmental quality (Clergeau et al., 1998) and insufficient vegetation (Beissinger and Osborne, 1982) and hence, their preponderance could be attributed to higher resource availability, e.g. trees and open areas (Lim and Sodhi, 2004) at semi-urban, semi-rural and rural-natural compared to urban site. The occurrence of bird from nectivorous guild at rural site only might be due to the flowering plant species.

\section{Conclusions}

Urban site supports low richness and diversity of birds than other urbanization gradient sites. Richness and diversity of avifauna reaches its peak at semi-natural site. Urban site was found to be dominated by omnivore guild which was replaced by insectivore guild at other urbanization gradient sites. The present study supports intermediate disturbance hypothesis of higher bird richness and diversity at moderate disturbance.

\section{Acknowledgements}

The first author is thankful to Mr. Shiraj Majoomdar and Mr. Rohit Chaudhary for rendering their help during the field work. This research did not receive any specific grant from funding agencies in the public, commercial, or not-for-profit sectors.

\section{Conflict of Interest}

The authors declare that there are no conflicts of interest related to this article.

\section{References}

Ali S, Ripley SD (1987). Handbook of the birds of India and Pakistan. Oxford University Press, NewDelhi.

Beissinger SR, Osborne DR (1982). Effects of urbanization on avian community organization. Condor 84:75-83.

Bhatt D, Joshi KK (2011). Bird assemblages in natural and urbanized habitats along elevational gradient in Nainital district (western Himalaya) of Uttarakhand state, India. Current Zoology 57(3):318329.

Blair RB (1996). Land use and avian species diversity alongan urban gradient. Ecological Application 6:506-519.

Bohning-Gaese K (1997). Determinants of avian species richness at different spatial scales. Journal of Biogeography 24:49-60.

Bolger DT, Scott TA, RotenberryJT (1997). Breedingbird abundance in an urbanizing landscape in coastal southern California. Conservation Biology 11:406-421.

Bonilla EP, León-Cortés JL, Rangel-Salazar JL (2012). Diversity of bird feeding guilds in relation to habitat heterogeneity and land-use cover in a human modified landscape in southern Mexico. Tropical Ecology 28:369-376.

Boren JC,Engle DM, Palmer MW, Masters RE, Criner T (1999).Land use change effects on breeding bird community composition. Journal of Range Management 52:420-430. 
Cencus of India (2011). District census handbook: Aligarh, village and town wise. Directorate ofCensus Operations, Uttar Pradesh.

Chace JF, Walsh JJ (2006). Urban effects on native avifauna: a review. Landscape Urban Planning 74:46-69.

Clergeau P, Savard JP, Mennechez G, Falerdau G (1998). Bird abundance and diversity along an urban-rural gradient: a comparative study between two cities on different continents. Condor 100:413-425.

Connell JH (1978). Diversity in tropical rain forests and coral reefs. Science 199:1302-1310.

Conole, LE, Kirkpatrick JB (2011). Functional and spatial differentiation of urban bird assemblages at the landscape scale. Landscape Urban Planning 100(1-2):11-23.

Fahrig L, Baudry J, Brotons L, Burel FG, Crist TO, Fuller RJ, ... Martin JL (2011). Functional landscape heterogeneity and animal biodiversity in agricultural landscapes. Ecology Letters 14:101-112.

Farooq S, Ahmad S (2008). Urban sprawl development around Aligarh City: A case study aided by satellite remote sensing and GIS. Journal of Indian Society of Remote Sensing 36:77-88.

Garaffa PI, Filloy J, Bellocq IM (2009). Bird community responses along urban-rural gradients: does the size of the urbanized area matter? Landscape Urban Planning90:33-41.

Graham, JH, Duda JJ (2011). The humpbacked species richness-curve: A contingent rule for community ecology. International Journal of Ecology 868426:1-15.

Grimmett R, Inskipp C, Inskipp T (2015). Birds of the Indian subcontinent. Oxford University Press, New Delhi.

Jokimaki J, Clergeau P, Kaisanlahti-Jokimaki ML (2002). Winter bird communities in urban habitats: a comparative study between central and northern Europe. Journal of Biogeography 29(1):69-79.

Jokimaki J, Suhonen J (1993). Effects of urbanization on the breeding bird species richness in Finland: A biogeographical comparison. Ornis Fennica 70(2):71-77.

Kale M,Dude N, Kasambe R, Chakane S, Bahttacharya P(2011).Impact of urbanization avian population and its status in Maharashtra state, India. International Journal of AppliedEnvironmental Sciences 7(1):59-76.

Kale M, Ferrante M, Nandkishor D, Kasambe R, Trukhanova IS, Ivanova T, ... Lövei GL (2018). Nestedness of bird assemblages along an urbanisation gradient in Central India. Journal of Urban Ecology $4(1): 1-8$.

KarkS, Iwaniuk A, Schalimtzek A, Banker E (2007). Living in the city: Can anyone become an 'urban exploiter'? Journal of Biogeography 34(4):638-651.

Katayama N, Amano T, Naoe S, Yamakita T, Komatsu I, Takagawa S, ... Miyashita T (2014). Landscape heterogeneity-biodiversity relationship: effect of range size. PLoS One 9(3):e93359.

Koparde P, Raote N (2016). Areas of avian richness across an urban-rural setting: a case study of selected water-bodies from Pune, Maharashtra, India. Indian Birds 12(2-3):50-55

Lepage D (2017). Checklist of the birds of Aligarh \& Environs. Avibase, the world bird database. Retrieved 2017 September 17 from http://avibase.bsceoc.org/checklist.jpp?lang=ENE'region=inggup07نrlist $=$ howardmoore \& format $=2$.

Lepczyk CA, Flather CH, RadeloffVC, Pidgeon AM, Hammer RB, Liu J
(2008). Human impacts on regional avian diversity. Conservation Biology 22:405-416.

Leveau LM, Leveau CM, Villegas M, Cursach JA, Suazo CG (2017). Bird communities along urbanization gradients: a comparative analysis among three neotropical cities. Ornitologia Neotropical 28:77-87.

Lim HC, Sodhi NS (2004). Responses of avian guilds to urbanisation in a tropical city. Landscape Urban Planning 66(4):199-215.

Magle SB, Angeloni LM (2010). Effects of urbanization on the behaviour of a keystone species. Behaviour 148:31-54.

Marzluff JM (2001). Worldwide urbanization and its effects on birds. In: Marzluff JM, Bowman R, Donnelly R (Eds). Avian ecology in an urbanizingworld. Kluwer, Norwell pp 19-47.

McKinney M (2006). Urbanization as a major cause of biotic homogenization. Biological Conservation 127:247-260.

McKinney ML (2002). Urbanization, biodiversity, and conservation. Bioscience 52:883-890.

McKinney ML (2006). Urbanization as a major cause of biotic homogenization. Biological Conservation 127(3):247-260.

McKinney ML (2008). Effects of urbanization on species richness: a review of plants and animals. Urban Ecosystem 11(2):161-176.

Miller JR, Wiens JA, Hobbs NT, Theobald DM (2003) Effects of human settlement on bird communities in lowland riparian areas of Colorado (USA). Ecological Applications 13:1041-1059.

Mondak BK (2017). Impact of urbanization on House sparrow distribution: A case study from Greater Kolkata, India. Proceedings of the Zoological Society 17(1):21-27.

Naithani A, Bhatt D (2012). Bird community structure in natural and urbanized habitats along an altitudinal gradient in Pauri district (Garhwal Himalaya) of Uttarakhand state, India. Biologia 67(4):1-9.

Pal M, Pop P, Mahapatra A, Bhagaat R, Hore U (2019). Diversity and structure of bird assemblages along urban-rural gradient in Kolkata, India. Urban Forestry and Urban Greening 38:8496.

Pauchard A, Aguayo M, Pena E, Urrutia R (2006). Multiple effects of urbanization on the biodiversity of developing countries: the case of a fast-growing metropolitan area (Concepcio'n, Chile). Biological Conservation 127:272-28.

Sanz V, Caula S (2014). Assessing bird assemblages along an urban gradient in a Caribbean island (Margarita, Venezuela). Urban Ecosystem 18 (3):729-746.

Sara M, Vittorio MD (2003). Factors influencing the distribution, abundance and nest-site selection of an endangered Egyptian vulture (Neophron percnopterus) population in Sicily. Animal Conservation Forum 6(4):317-328.

SenguptaS, Mondal M, Basu P (2013). Bird species assemblages across a rural urban gradient around Kolkata, India. Urban Ecosystem 17(2):585596.

Seress G, Liker A (2015). Habitat urbanization and its effects on birds. Acta Zoologica Academiae Scientiarum Hungaricae 61(4):373-408.

Summers-Smith JD (2003). Decline of the house sparrow: a review. British Birds 96:439-446.

UN-Habitat (2016). Urbanization and development: emerging future. World's Cities 2016. Retrived 2017 July 17 from http://wcr.unhabitat.org/main-report/\#section_eleven. 